Cooperative Research Unit

Prepared in cooperation with the Wisconsin Department of Natural Resources, the City of Madison, Fund for Lake Michigan, Yahara Watershed Improvement Network, Dane County Land and Water Resources, Clean Lakes Alliance, League of Wisconsin Municipalities, and DuPage River Salt Creek Workgroup

\title{
Reducing Leaf Litter Contributions of Phosphorus and Nitrogen to Urban Stormwater through Municipal Leaf Collection and Street Cleaning Practices
}

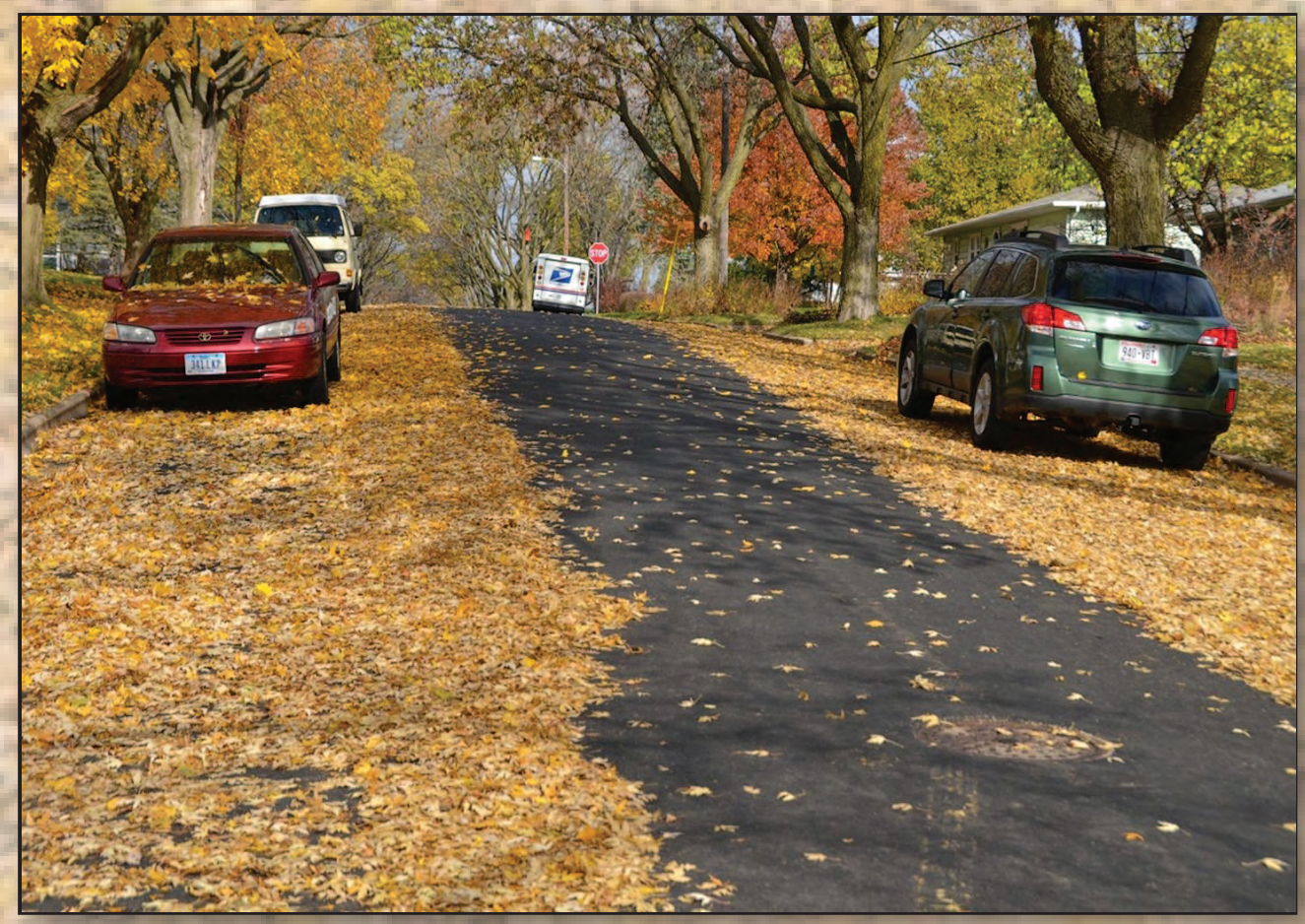

Scientific Investigations Report 2020-5109 
Cover photographs. Excessive leaf litter accumulated on residential streets. Photograph by Roger Bannerman, U.S. Geological Survey. 


\section{Reducing Leaf Litter Contributions of Phosphorus and Nitrogen to Urban Stormwater through Municipal Leaf Collection and Street Cleaning Practices}

By William R. Selbig, Nicolas H. Buer, Roger T. Bannerman, and Phillip Gaebler

Cooperative Research Unit

Prepared in cooperation with the Wisconsin Department of Natural Resources, the City of Madison, Fund for Lake Michigan, Yahara Watershed Improvement Network, Dane County Land and Water Resources, Clean Lakes Alliance, League of Wisconsin Municipalities, and DuPage River Salt Creek Workgroup

Scientific Investigations Report 2020-5109 


\title{
U.S. Department of the Interior \\ DAVID BERNHARDT, Secretary
}

\author{
U.S. Geological Survey \\ James F. Reilly II, Director
}

U.S. Geological Survey, Reston, Virginia: 2020

For more information on the USGS - the Federal source for science about the Earth, its natural and living resources, natural hazards, and the environment—visit https://www.usgs.gov or call 1-888-ASK-USGS.

For an overview of USGS information products, including maps, imagery, and publications, visit https://store.usgs.gov/.

Any use of trade, firm, or product names is for descriptive purposes only and does not imply endorsement by the U.S. Government.

Although this information product, for the most part, is in the public domain, it also may contain copyrighted materials as noted in the text. Permission to reproduce copyrighted items must be secured from the copyright owner.

Suggested citation:

Selbig, W.R., Buer, N.H., Bannerman, R.T., and Gaebler, P., 2020, Reducing leaf litter contributions of phosphorus and nitrogen to urban stormwater through municipal leaf collection and street cleaning practices: U.S. Geological Survey Scientific Investigations Report 5109, 17 p., https://doi.org/10.3133/sir20205109.

Associated data for this publication:

Carvin, R.B., and Selbig, W.R., 2020, Stormwater-quality data in the control and test catchments during the calibration and treatment phase of a leaf collection study in Madison, Fond du Lac, and Oshkosh,

Wisconsin, from September 2016 through November 2019: U.S. Geological Survey data release,

https://doi.org/ 10.5066/ P93L2WM1.

ISSN 2328-0328 (online) 


\section{Contents}

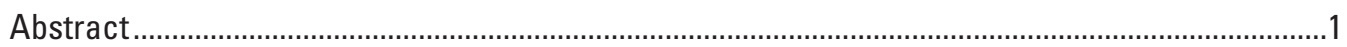

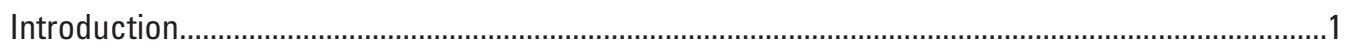

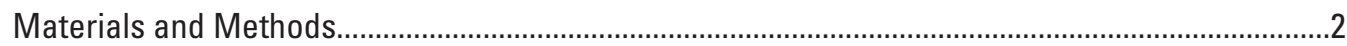

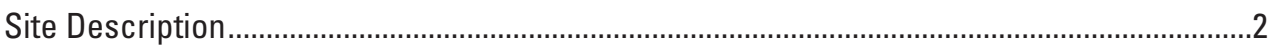

Sample Collection and Measurement of Nutrient Concentrations .........................................4

Leaf Collection and Street Cleaning Practices .....................................................................

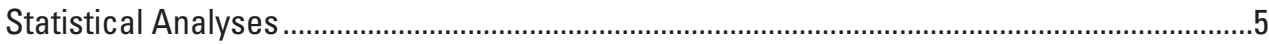

Nutrient Concentrations in Stormwater and Reduction in Nutrient Load from Municipal Leaf Collection and Street Cleaning Practices ................................................................

Nutrient Concentrations in Stormwater With and Without Treatment....................................6

Reduction in Nutrient Load from Municipal Leaf Collection and Street Cleaning

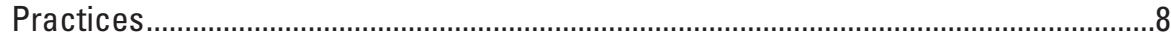

Implications for Urban Stormwater Management .......................................................................13

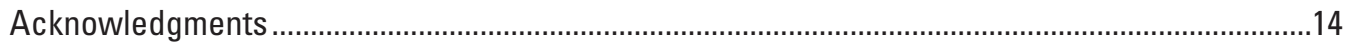

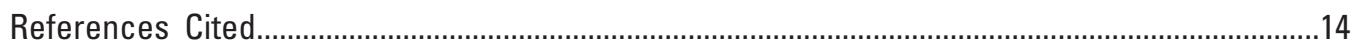

Appendix 1. Paired-Basin Nutrient Loads in the Control and Test Catchments During

Calibration and Treatment Phases ...................................................................................17

\section{Figures}

1 Map showing location of study catchments in the cities of Madison, Fond du Lac, and Oshkosh, Wisconsin.

2. Graphs showing site mean plus or minus standard error of $A$, event total phosphorus and dissolved phosphorus concentration and $B$, event total nitrogen and dissolved nitrogen concentration during a period of no leaf collection or street cleaning compared against the percentage of streets covered by tree canopy.

3. Graphs showing site mean plus or minus standard error of $A$, event total phosphorus and dissolved phosphorus concentration and $B$, event total nitrogen and dissolved nitrogen concentration after treatment compared against the percentage of streets covered by tree canopy.

4. Graph showing log-transformed total phosphorus load for paired samples collected in the control and test catchment during the calibration and V1-R1 treatment phase

5. Graphs showing percent reduction of $A$, event total phosphorus and dissolved phosphorus load and $B$, event total nitrogen and dissolved nitrogen load after treatment compared against the percentage of streets covered by tree canopy

\section{Tables}

1. Description of source areas and tree canopy in the control and test catchments (rounding applied) .......................................................................................

2. Distribution of street tree species based on prevalence in each study catchment .........4

3. Combination of municipal leaf collection and street cleaning method and frequency evaluated for nutrient load reductions in stormwater runoff.............................5

4. Dissolved phosphorus and dissolved nitrogen as a percentage of the total fraction for paired samples collected during the calibration and treatment phases .....10 


\section{Conversion Factors}

International System of Units to U.S. customary units

\begin{tabular}{|c|c|c|}
\hline Multiply & By & To obtain \\
\hline \multicolumn{3}{|c|}{ Length } \\
\hline millimeter (mm) & 0.03937 & inch (in.) \\
\hline centimeter $(\mathrm{cm})$ & 0.3937 & inch (in.) \\
\hline \multicolumn{3}{|c|}{ Area } \\
\hline hectare (ha) & 2.471 & acre \\
\hline \multicolumn{3}{|c|}{ Flow rate } \\
\hline meter per second $(\mathrm{m} / \mathrm{s})$ & 3.281 & foot per second $(\mathrm{ft} / \mathrm{s})$ \\
\hline \multicolumn{3}{|c|}{ Mass } \\
\hline microgram $(\mu \mathrm{g})$ & 0.00000003527 & ounce, avoirdupois (oz) \\
\hline
\end{tabular}

Temperature in degrees Celsius $\left({ }^{\circ} \mathrm{C}\right)$ may be converted to degrees Fahrenheit $\left({ }^{\circ} \mathrm{F}\right)$ as follows:

$$
{ }^{\circ} \mathrm{F}=\left(1.8 \times{ }^{\circ} \mathrm{C}\right)+32 .
$$

Temperature in degrees Fahrenheit $\left({ }^{\circ} \mathrm{F}\right)$ may be converted to degrees Celsius $\left({ }^{\circ} \mathrm{C}\right)$ as follows:

$$
{ }^{\circ} \mathrm{C}=\left({ }^{\circ} \mathrm{F}-32\right) / 1.8 \text {. }
$$

\section{Supplemental Information}

Concentrations of chemical constituents in water are given in either milligrams per liter (mg/L).

\section{Abbreviations}

$\begin{array}{ll}\text { ANCOVA } & \text { analysis of covariance } \\ \text { DN } & \text { dissolved nitrogen } \\ \text { DP } & \text { dissolved phosphorus } \\ \text { EPA } & \text { U.S. Environmental Protection Agency } \\ \text { EMC } & \text { event mean concentration } \\ \text { TN } & \text { total nitrogen } \\ \text { TP } & \text { total phosphorus }\end{array}$




\title{
Reducing Leaf Litter Contributions of Phosphorus and Nitrogen to Urban Stormwater through Municipal Leaf Collection and Street Cleaning Practices
}

\author{
By William R. Selbig, ${ }^{1}$ Nicolas H. Buer, ${ }^{1}$ Roger T. Bannerman, ${ }^{2}$ and Phillip Gaebler ${ }^{3}$
}

\section{Abstract}

As the boundaries of urban land use continue to expand, environmental managers are looking for innovative ways to reduce export of nutrients from urban sources. Municipal services such as leaf collection and street cleaning have the potential to reduce nutrient pollution at its source while continuing to offer services valued by residents. This study characterized reductions of total and dissolved forms of phosphorus and nitrogen in stormwater runoff from paired catchments, testing the method and frequency of municipal leaf collection and street cleaning programs.

Overall, the performance of municipal programs was related to the frequency and not the form of treatment. Catchments receiving a weekly street cleaning by a regenerative-air street cleaner had the highest reduction in phosphorus load, ranging from 65 to 71 percent (probability value $[p]$ is less than 0.05 ) for total phosphorus and 57 to 70 percent ( $p$ is less than 0.05) for dissolved phosphorus, regardless of leaf collection method or frequency. Reduction in nitrogen load was generally mixed, with many of the catchments showing no statistically significant changes after treatment. In general, nutrient concentrations, and subsequent percent reduction of nutrient loads, were positively correlated with street tree canopy. Collection of only leaf piles, leaving streets unswept, showed no significant reduction in loads of total or dissolved phosphorus and an 83 percent increase in load of total nitrogen. The majority of nutrient concentrations were in the dissolved fraction making source control through leaf collection and street cleaning more effective at reducing the amount of dissolved nutrients in stormwater runoff than structural practices such as wet detention ponds. Based on the results of this study, municipal leaf management programs would be most effective with weekly street cleaning in areas of high street tree canopy, whereas the method and frequency of leaf pile collection is of less importance to the mitigation of nutrients in stormwater runoff.

\footnotetext{
${ }^{1}$ U.S. Geological Survey.

${ }^{2}$ Wisconsin Department of Natural Resources (retired).

${ }^{3}$ City of Madison-Department of Engineering.
}

\section{Introduction}

The combined effect of phosphorus and nitrogen enrichment from accelerated expansion of urban land use has resulted in increased eutrophication, higher occurrence of harmful algal blooms, and loss in recreational value for receiving water bodies across the world (Moore and others, 2003; Yang and Toor, 2018; Wurtsbaugh and others, 2019) The most effective management actions to reduce these negative effects are continued efforts to reduce enriched phosphorus and nitrogen from entering our waters (Gilbert and Burford, 2017). Understanding the sources and abundance of nutrients in the urban landscape, and mobility to storm drains is an important step in developing management plans. Among the many sources of phosphorus and nitrogen in urban catchments, vegetated areas have been shown to be the highest contributors to stormwater runoff (Steuer and others, 1997; Waschbusch and others, 1999; Shaver and others, 2007; Müller and others, 2020).

Urban areas, having a high percentage of impervious surfaces, can effectively transport nutrients leached from vegetated sources to the storm drainage network where they are quickly routed to nearby receiving waters. Nutrients primarily come from decomposing plant material such as grass clippings, yard waste, and leaf litter. In a study of seven urban watersheds in metropolitan areas of Minnesota, Hobbie and others (2017) reported high export of phosphorus and nitrogen, but in contrasting pathways. Export via stormwater runoff was greatest for phosphorus, while nitrogen showed greater retention with losses coming primarily by way of denitrification and leaching to groundwater. Hobbie and others (2017) suggest phosphorus mitigation would benefit from a focus on the transfer of phosphorus-rich runoff from vegetated landscapes to streets, whereas mitigation of nitrogen was narrowed to reducing watershed inputs. Historically, stormwater management strategies have focused on localized or regional best management practices and green infrastructure when dealing with runoff (for example, bioretention, rain gardens, and detention ponds), many of which are primarily intended to reduce the volume of runoff with water-quality treatment a secondary benefit. Nutrient removal efficiency of 
these practices can be variable, with performance often tied to soil conditions, microbial activity, and plant uptake (Jaffe and others, 2010). Frequently, best management practices also require tracts of land, sometimes of appreciable size, placed in strategic locations. However, cities are often faced with limited open space available for the construction of new structural practices. While the possibility of retrofitting existing areas remains an option, costs may be prohibitive. Furthermore, cities around the country that are subject to the development of total maximum daily loads for impaired waters, the maximum amount of pollutant a water body can receive to maintain beneficial use (U.S Environmental Protection Agency, 2020), may find structural practices are not able to provide a sufficient level of treatment. Nonstructural options, such as removing pollutants at their source through leaf collection and street cleaning, can be another viable option for mangers to consider when developing stormwater management plans.

Improving our knowledge of the potential reduction of nutrients to stormwater through removal of leaves and other organic detritus on streets could help tailor more targeted municipal leaf collection programs. Results from studies evaluating the pollutant removal efficiency of street cleaners are mixed. Some conclude that street cleaning can be an effective tool for nutrient management in urban areas based on the evaluation of material collected in the hopper of a street cleaner (for example, Baker and others, 2014); however, many other studies have shown street cleaning, while efficient at removing an appreciable amount of solids and debris from street surfaces, are largely ineffective at improving the quality of stormwater runoff (Selbig and Bannerman, 2007; Law and others, 2008; Sorenson, 2012). A review of available literature found no studies quantifying municipal leaf collection as a source control practice for the reduction of nutrients in stormwater. Research dating back to the early 1970s (for example, Cowen and Lee, 1973) has characterized the nutrient content of leaf litter on streets with speculation on the potential for reductions to stormwater if removed via leaf collection and street cleaning. More recently, Janke and others (2017) found a strong positive relation between nutrient concentrations in stormwater and the percentage of street tree canopy in an urban catchment. Janke and others (2017) conclude that effective management strategies include targeting trees and leaf litter. A similar conclusion was made by Hobbie and others $(2014,2017)$ and Bratt and others (2017) when examining the fate and transport of phosphorus and nitrogen from urban landscapes. Selbig (2016), in a more direct measurement of nutrient reduction by removal of leaf litter on streets, used high-powered leaf blowers to remove all organic detritus from the street before a precipitation event. The intent was to characterize a "best case scenario" for municipal operations. While this extra measure of leaf removal exceeds the capabilities of most municipal leaf collection programs, it set a benchmark for the greatest potential reduction of nutrients in runoff through removal of leaves and other organic detritus from urban streets with canopy cover. Results showed more than an 80 percent reduction in total phosphorus (TP) and dissolved phosphorus (DP) load compared to no leaf collection and street cleaning. Because this represented an upper maximal effort, Selbig (2016) concluded municipal leaf collection programs would likely result in lower reductions in TP and DP with efficiency, frequency, and timing of leaf removal and street cleaning being the primary factors in these efforts. Selbig (2016) also noted that additional research would be needed to quantify the range in method and frequency of existing municipal leaf collection and street cleaning programs so cities can evaluate the potential nutrient reduction of their own practices compared to others.

The purpose of this study was to determine if, and by how much, removing leaves and other organic detritus from streets, through municipal leaf collection and street cleaning programs, could reduce nutrient contributions to local water bodies. Concentrations and loads of phosphorus and nitrogen in stormwater runoff were measured from paired medium-density residential catchments during the fall. One catchment was established as a control in which there was no effort to remove leaf litter and other organic detritus from streets. The second catchment served as the test catchment in which removal of leaf litter was done through a combination of municipal leaf collection and street cleaning on a weekly or biweekly schedule. This study supports an ongoing effort to identify existing and new methods to reduce nonpoint source pollution from urban areas.

\section{Materials and Methods}

This section of the report describes the materials and methods used in this study, including a description of the study sites in Wisconsin. Methods for sample collection and measurement of nutrient concentrations and leaf collection and street cleaning practices also are described. The statistical analyses used in this study are described.

\section{Site Description}

This study characterized concentrations of phosphorus and nitrogen in urban stormwater runoff from nine residential catchments distributed among three Wisconsin cities (fig. 1). Catchments were selected to represent typical medium-density residential land use with varying overhead tree canopy.

Distance between study catchments within each city was minimized to limit variability in precipitation patterns. Catchment monitoring for characterization of nutrient concentrations and loads occurred during the fall of each year over a span of 7 years (2013-2019); however, not all catchments were monitored in each year. Although the fall equinox officially occurs in late September, accumulation of leaf litter does not typically start until shortly after leaf senescence in early October continuing through mid to late November. 


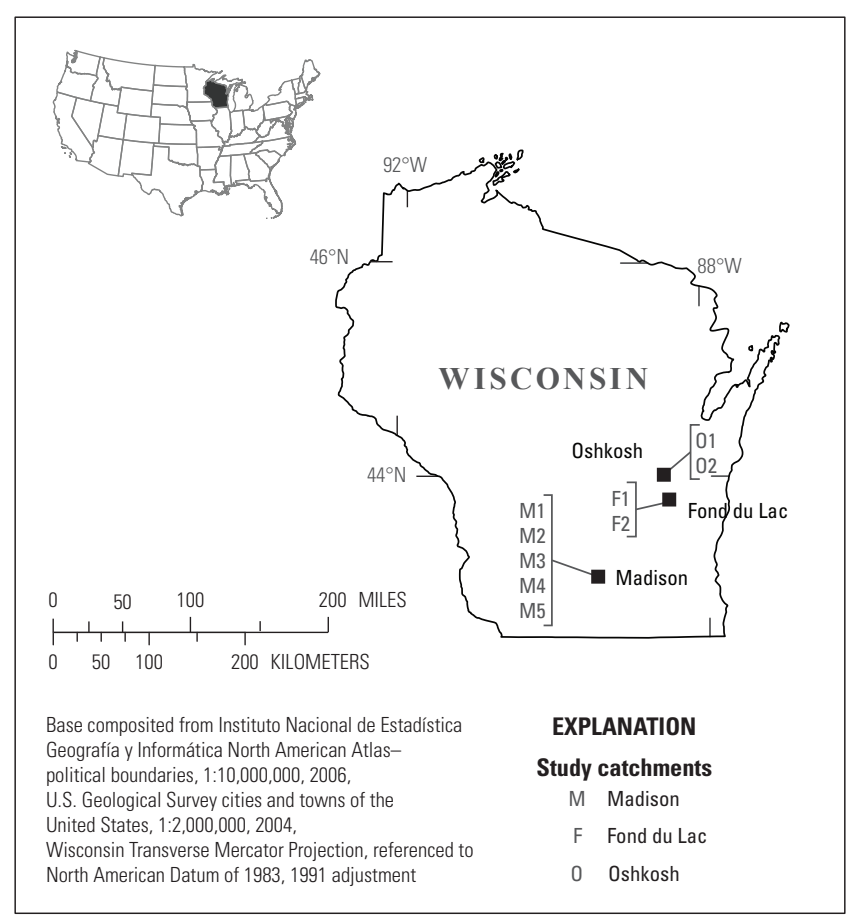

Estimates of the source area and overhead tree canopy were made using a combination of aerial imagery, geographic information system (GIS) software, and field surveys (table 1). Each catchment had a similar distribution of source areas with lawns having the greatest percentage. The percentage of tree canopy covering streets ranged from 4 to 67 percent (table 1). Trees were generally a mix of mature deciduous hard and softwood species with the majority being characterized as Acer platanoides (Norway maple), Acer Saccharum (sugar maple), Gleditsia tricanthos L. (honey locust), and Fraxinus pennsylvanica Marsh (green ash) (table 2). The amount of leachable phosphorus can vary appreciably amongst different tree species. Dorney (1986) reported concentrations of leachable phosphorus from 52 intact tree leaves representing 13 species in Milwaukee, Wisconsin, ranged from 20 to 411 micrograms per gram $(\mu \mathrm{g} / \mathrm{g})$. Therefore, the range of nutrient concentrations reported herein may not be like other areas with different tree species.

Figure 1. Location of study catchments in the cities of Madison, Fond du Lac, and Oshkosh, Wisconsin.

Table 1. Description of source areas and tree canopy in the control and test catchments (rounding applied).

$[\%$, percent; <, less than]

\begin{tabular}{|c|c|c|c|c|c|c|c|c|}
\hline \multicolumn{9}{|c|}{ Catchment } \\
\hline M1 & M2 & M3 & M4 & M5 & F1 & F2 & 01 & 02 \\
\hline \multicolumn{9}{|c|}{ Drainage area (hectares) } \\
\hline 1.21 & 6.47 & 11.21 & 5.39 & 6.83 & 2.04 & 6.31 & 7.22 & 5.22 \\
\hline \multicolumn{9}{|c|}{ Source area (\%) } \\
\hline \multicolumn{9}{|c|}{ Streets } \\
\hline 19 & 17 & 15 & 16 & 19 & 19 & 11 & 14 & 15 \\
\hline \multicolumn{9}{|c|}{ Driveways } \\
\hline 4 & 6 & 5 & 8 & 10 & 10 & 6 & 5 & 7 \\
\hline \multicolumn{9}{|c|}{ Roofs } \\
\hline 19 & 17 & 18 & 14 & 13 & 18 & 18 & 20 & 18 \\
\hline \multicolumn{9}{|c|}{ Sidewalks } \\
\hline 3 & 5 & 5 & 4 & 2 & 7 & 3 & 4 & 4 \\
\hline \multicolumn{9}{|c|}{ Lawns/open } \\
\hline 54 & 55 & 57 & 58 & 55 & 46 & 60 & 56 & 55 \\
\hline \multicolumn{9}{|c|}{ Other impervious } \\
\hline 0 & $<1$ & 0 & 0 & 0 & 0 & 1 & 1 & 0 \\
\hline \multicolumn{9}{|c|}{ Catchment tree canopy (\%) } \\
\hline 71 & 39 & 55 & 24 & 27 & 25 & 16 & 8 & 13 \\
\hline \multicolumn{9}{|c|}{ Street tree canopy (\%) } \\
\hline 67 & 41 & 51 & 21 & 27 & 30 & 17 & 4 & 11 \\
\hline
\end{tabular}


Table 2. Distribution of street tree species based on prevalence in each study catchment. All values expressed as a percent of the total number of street trees.

[--, not present]

\begin{tabular}{lcccc}
\hline Catchment & Norway maple & Sugar maple & Honey locust & Green ash \\
\hline M1 & 50 & 20 & 10 & 20 \\
M2 & 50 & -- & -- & 26 \\
M3 & 20 & 21 & 1 & 18 \\
M4 & 35 & -- & 25 & 20 \\
M5 & 23 & -- & 17 & 39 \\
F1 & 57 & -- & -- & 33 \\
F2 & 53 & -- & 15 & 13 \\
\hline O1 & 2 & -- & -- & 79 \\
\hline O2 & 2 & -- & 2 & 88 \\
\hline
\end{tabular}

\section{Sample Collection and Measurement of Nutrient Concentrations}

A monitoring station at both the control and test catchment was used to measure flow and collect water samples at the storm sewer outfall. Each monitoring station was equipped with automated stormwater-quality samplers with a sample orifice diameter of approximately 9.5 millimeters $(\mathrm{mm})$ and withdrawal velocity of approximately 0.9 meter per second. Low-profile sensors were used to measure water level (calibrated to plus or minus $6 \mathrm{~mm}$ ) and velocity to compute discharge. Precipitation data were collected by use of a tippingbucket rain gage calibrated to $0.25 \mathrm{~mm}$ per tip.

Sample collection was activated by a rise in water level in the storm sewer pipe during a precipitation event. Once a water-level threshold was exceeded, typically a depth of 1.2 centimeters from the pipe floor, the volume of water passing the station was measured and accumulated at 1-minute increments until a volumetric threshold was reached. At that point, a depth-integrated sample arm sampler (Selbig and others, 2012) collected a discrete water sample, and the volumetric counter was reset. The small pipe diameter at catchments F1 and F2 restricted the use of a depth-integrated sample arm, so the sample intake was fixed approximately 1.3 centimeters off the pipe floor. The process was repeated until the water level receded below the threshold. All flow-weighted discrete samples collected over the duration of an event hydrograph were combined into a single composite sample resulting in an event mean concentration (EMC). Water-quality samples were typically collected within 24 hours after runoff cessation. A Teflon churn splitter was used to composite and split samples into smaller plastic sample containers for delivery to the analytical laboratory. A portion of the composite sample was processed through a 0.45 -micrometer filter for analyses of dissolved constituents. Processed samples were kept in a refrigerator at 4 degrees Celsius $\left({ }^{\circ} \mathrm{C}\right)$ until delivered to the analytical laboratory. Samples were analyzed at the Wisconsin
State Laboratory of Hygiene, in Madison, Wis. All samples were tested for TP and DP according to U.S. Environmental Protection Agency (EPA) Method 200.7 (EPA, 2001), and total nitrogen (TN) and dissolved nitrogen (DN) were tested according to EPA Method 353.2 (EPA, 1993).

\section{Leaf Collection and Street Cleaning Practices}

Municipal leaf collection in the State of Wisconsin typically begins in late September to early October of each year and continues through November, or until snowfall precludes further collection. Leaf collection vehicles are deployed to collect and remove bulk leaf litter and other organic detritus from residential areas. Residents are asked to pile their leaves adjacent to the street to limit excess debris in the street gutter. After leaf piles are removed, street cleaners pass through the service area to remove leftover organic residue from the street and gutter.

Table 3 describes the combination of leaf collection, street cleaning, and frequency for each treatment catchment. Although the methods described in table 3 are not inclusive of all municipal leaf management options, they represent practices that are more commonly used by Wisconsin cities. The first method, herein described as "transfer," uses a vehicle equipped with a modified bristled plow to rapidly transfer piles of leaves placed near the curb into the street. The leaves are then pushed into a garbage collection vehicle for removal. The second method, herein described as "vacuum-mulch," uses a truck- or trailer-mounted high-suction vacuum to suck leaf piles through a mulching blade before discharging the shredded leaves into a truck to be hauled away. A regenerativeair or mechanical-broom street cleaner, like those described by Selbig and Bannerman (2007), serviced the area the same day or as soon as possible (typically within a few days) following leaf collection to remove any residual organic debris from the street and gutter. The frequency of leaf collection and street 
cleaning varied from once per week to approximately every 14 days (herein referred to as "biweekly"). The control catchments remained without any leaf collection or street cleaning.

For simplicity, an abbreviation of the eight paired catchments was assigned based on the combination of leaf collection and street cleaning method and frequency (table 3). For example, T2-M1 describes a paired catchment that evaluated a transfer leaf collection method at a biweekly frequency and a mechanical broom street cleaning method at a frequency of once per week.

Leaf collection and street cleaning practices were modified in two paired catchments to characterize nutrient contributions (and the impact of their removal) from only leaf litter in streets and only leaves piled adjacent to streets. In 2018, biweekly collection of leaf piles in the M1 catchment was done without street cleaning (named V2 in table 3). This scenario was done to isolate the effect of collecting only leaf piles. In 2019, the effect of collecting only leaf litter from streets was tested in the $\mathrm{O} 2$ catchment by use of a regenerative-air street cleaner on a weekly basis while leaf piles remained in place (named R1 in table 3).

\section{Statistical Analyses}

A paired-catchment design was used to help evaluate the effectiveness of leaf collection based on differences in loads of phosphorus and nitrogen in the control and test catchment between calibration and treatment phases of the project. The basis behind the paired-catchment approach is that there is a quantifiable relation between paired water-quality data and that this relation is valid until a major change (treatment) is made in one of the catchments (Clausen and Spooner, 1993). At that time, a new relation will develop. The strength of this approach is that it does not require the assumption that the control and test catchments are statistically the same; however, it does require that the two catchments respond in a predictable manner together and that their relation remains the same over time except for the effect of leaf collection and street cleaning.

Following procedures outlined in Clausen and Spooner (1993), the significance of the relation between logtransformed paired water-quality data during each phase was confirmed using the analysis of variance (probability value $[p]=0.05$ ). At the end of the treatment phase, the significance of the effect of leaf collection and street cleaning was determined using analysis of covariance (ANCOVA) (Clausen and Spooner, 1993). ANCOVA is a series of steps determining the significance of the treatment regression, the significance of the overall regression which combines the calibration and treatment phase data, the difference between the slopes of the calibration and treatment regressions, and the difference between the intercepts of the calibration and treatment regressions. A change in intercepts, but not slopes, between the calibration and treatment phase indicates an overall parallel shift in the regression equation. If the treatment regression shifted below that of the calibration phase, the form of treatment can be considered effective at reducing nutrient loads. The existing municipal leaf management program for the $\mathrm{F} 2$ and $\mathrm{O} 2$ catchments was used as the calibration period, and the treatment for these catchments was no leaf collection or street cleaning in the F2 catchment and no leaf collection and weekly street cleaning in the $\mathrm{O} 2$ catchment. For these catchments, because the calibration period represents the existing leaf management program, a nutrient reduction from the leaf management program would be indicated by an upward vertical shift of the treatment regression from that of the calibration phase. No significant change in either the slope or intercept of the treatment regression indicates leaf removal had little to no effect on nutrient loads when compared to the calibration phase. Results were reported if they met the 85 percent significance level ( $p$ is less than $[<] 0.15$ ). If the results of the ANCOVA test

Table 3. Combination of municipal leaf collection and street cleaning method and frequency evaluated for nutrient load reductions in stormwater runoff. A naming convention for each paired catchment follows the format "leaf collection method and frequency (in weeks) —-street cleaning method and frequency (in weeks)," where $T$, transfer; $V$, vacuum-mulch; $R$, regenerative-air; $M$, mechanical broom.

$[--$, not done $]$

\begin{tabular}{ccclllll}
\hline \multirow{2}{*}{$\begin{array}{c}\text { Year } \\
\text { completed }\end{array}$} & \multicolumn{2}{c}{ Catchment } & \multicolumn{2}{c}{ Leaf collection } & \multicolumn{2}{c}{ Street cleaning } & \multirow{2}{*}{ Name } \\
\cline { 2 - 6 } & Treatment & Control & \multicolumn{1}{c}{ Method } & \multicolumn{1}{c}{ Frequency } & \multicolumn{1}{c}{ Method } & Frequency & \\
\hline 2016 & M2 & M1 & Transfer & Biweekly & Mechanical & Biweekly & T2-M2 \\
\hline 2017 & M2 & M1 & Transfer & Biweekly & Regenerative-air & Weekly & T2-R1 \\
2017 & M3 & M1 & Vacuum-mulch & Weekly & Regenerative-air & Weekly & V1-R1 \\
2018 & M5 & M4 & Transfer & Biweekly & Mechanical & Biweekly & T2-M2 \\
2018 & M1 & M2 & Vacuum-mulch & Biweekly & -- & - & V2 \\
2018 & M3 & M4 & Transfer & Biweekly & Regenerative-air & Weekly & T2-R1 \\
2019 & F2 & F1 & Vacuum-mulch & Weekly & Mechanical & Weekly & V1-M1 \\
\hline 2019 & O2 & O1 & -- & -- & Regenerative-air & Weekly & R1 \\
\hline
\end{tabular}


for slope or intercept reveal a significant difference between the calibration and treatment regressions, the regression equation representing the calibration period can be used to predict what the mean runoff event loads should have been in the test catchment during the treatment period. The overall nutrient reduction due to leaf collection and street cleaning can then be expressed as a percentage change based on the mean predicted and observed values during the treatment phase (Clausen and Spooner, 1993).

Pearson correlation coefficients (Helsel and Hirsch, 2002) were computed to statistically determine the linear association between the magnitude of mean nutrient concentrations and loads to catchment characteristics identified in table 1. Evaluation of tree canopy was limited to only street trees because management of leaf litter on private property, such as composting or mulching on site, was not documented and most likely inconsistent between catchments. Variables were strongly collinear when the Pearon correlation coefficient $(r)$ is greater than $[>] 0.60$ and $p<0.05$.

\section{Nutrient Concentrations in Stormwater and Reduction in Nutrient Load from Municipal Leaf Collection and Street Cleaning Practices}

A total of 170 samples were collected over the study period creating 96 unique pairs representing 8 variations of municipal leaf collection and street cleaning practices and frequencies, with 37 and 59 paired samples representing the calibration and treatment phases, respectively. A complete list of paired concentrations and loads can be found in Carvin and Selbig (2020).

\section{Nutrient Concentrations in Stormwater With and Without Treatment}

Mean concentrations of TP and DP varied by an order of magnitude across all catchments in the fall when no leaf collection or street cleaning occurred (fig. $2 A$ ). $\mathrm{O} 2$ had the lowest mean concentration of TP and DP at 0.22 and 0.17 milligram per liter $(\mathrm{mg} / \mathrm{L})$, respectively, and M1 the highest at 2.47 and $2.26 \mathrm{mg} / \mathrm{L}$. Each catchment represented different percentages of street tree canopy across all study catchments with $\mathrm{O} 2$ being the lowest and M1 the highest. Mean concentrations of TP and DP showed a strong positive correlation with only the relative percentage of street tree canopy ( $r=0.82, p<0.05$ for TP and DP) (fig. $2 A)$. Study catchments having less than 30 percent street tree canopy resulted in mean TP concentrations of less than $1 \mathrm{mg} / \mathrm{L}$, whereas catchments having more than 40 percent street tree canopy showed mean concentrations of twice that value or more. Janke and others (2017) made similar conclusions performing an analysis of more than 2,300 measurements of nutrient concentrations from 19 urban watersheds surrounding Minneapolis and St. Paul, Minnesota. Variation in nutrient EMCs (TP, DP, TN, and total organic nitrogen), using simple linear regression models, was largely explained by the amount of tree canopy near the street, especially during the fall. This correlation was further supported by similar studies characterizing concentrations of nutrients in stormwater runoff as a function of street tree canopy (Waschbusch and others, 1999; Baker and others, 2014; Hobbie and others, 2014; Selbig, 2016).

The exception was M4 which, having only 21 percent street tree canopy, had a mean TP and DP concentration similar to catchments with twice the amount of canopy at approximately $2 \mathrm{mg} / \mathrm{L}$. It is unclear why phosphorus concentrations in M4 were higher than M2, despite having lower street tree canopy. One explanation could be related to the distribution and variety of street tree species in the catchments. There was a greater occurrence of Norway maple in the M2 catchment at 50 percent of all street tree species, compared to only 35 percent in M4; however, M4 had more honey locust at 25 percent compared to zero in M2 (table 2). In laboratory tests, Dorney (1986) determined Norway maple had one of the lowest concentrations of leachable phosphorus $(80.1 \mu \mathrm{g} / \mathrm{g})$ among the leaves of 13 different species tested, whereas honey locust had one of the highest $(176 \mu \mathrm{g} / \mathrm{g})$. Given the distribution of these two species in each catchment, more leachable phosphorus could have been derived from fewer honey locust trees in M4 than from a greater number of Norway maple trees in M2. Furthermore, based on visual observation, senescence of honey locust leaves generally occurred earlier in the fall than any other tree species. Early fall leaf litter in the M4 catchment, being mostly comprosed of honey locust, would have resulted in phosphorus concentrations and loads that would be greater than a catchment with similar leaf litter mass consisting of a mix of tree species. Therefore, the type and abundance of tree species can be factors when determining EMCs of phosphorus in stormwater runoff.

Nitrogen, unlike phosphorus, showed less disparity in mean concentration between catchments in the fall when no leaf collection or street cleaning occurred (fig. 2B). Mean concentrations of TN and DN ranged from 1.45 and $0.87 \mathrm{mg} / \mathrm{L}$ in the F2 catchment, respectively, to 3.04 and $2.11 \mathrm{mg} / \mathrm{L}$ in M1. Like phosphorus, mean concentrations of TN were lowest in catchments having less street canopy than those with higher street canopy, indicating a strong positive correlation for TN $(r=0.88, p<0.01)$. The effect of street tree canopy on stormwater TN concentration, especially in the fall, was similarly reported by Janke and others (2017). DN was moderately correlated to street tree canopy but failed to meet statistical significance $(r=0.67, p<0.10)$. In general, relations between mean concentrations of phosphorus and nitrogen were consistent; catchments with lower amounts of phosphorus would also produce lower amounts of nitrogen. Counter to this pattern was catchment M4 which had one of the highest mean concentrations of TP and DP, yet one of the lowest mean concentrations of TN and DN. Although TN was positively 

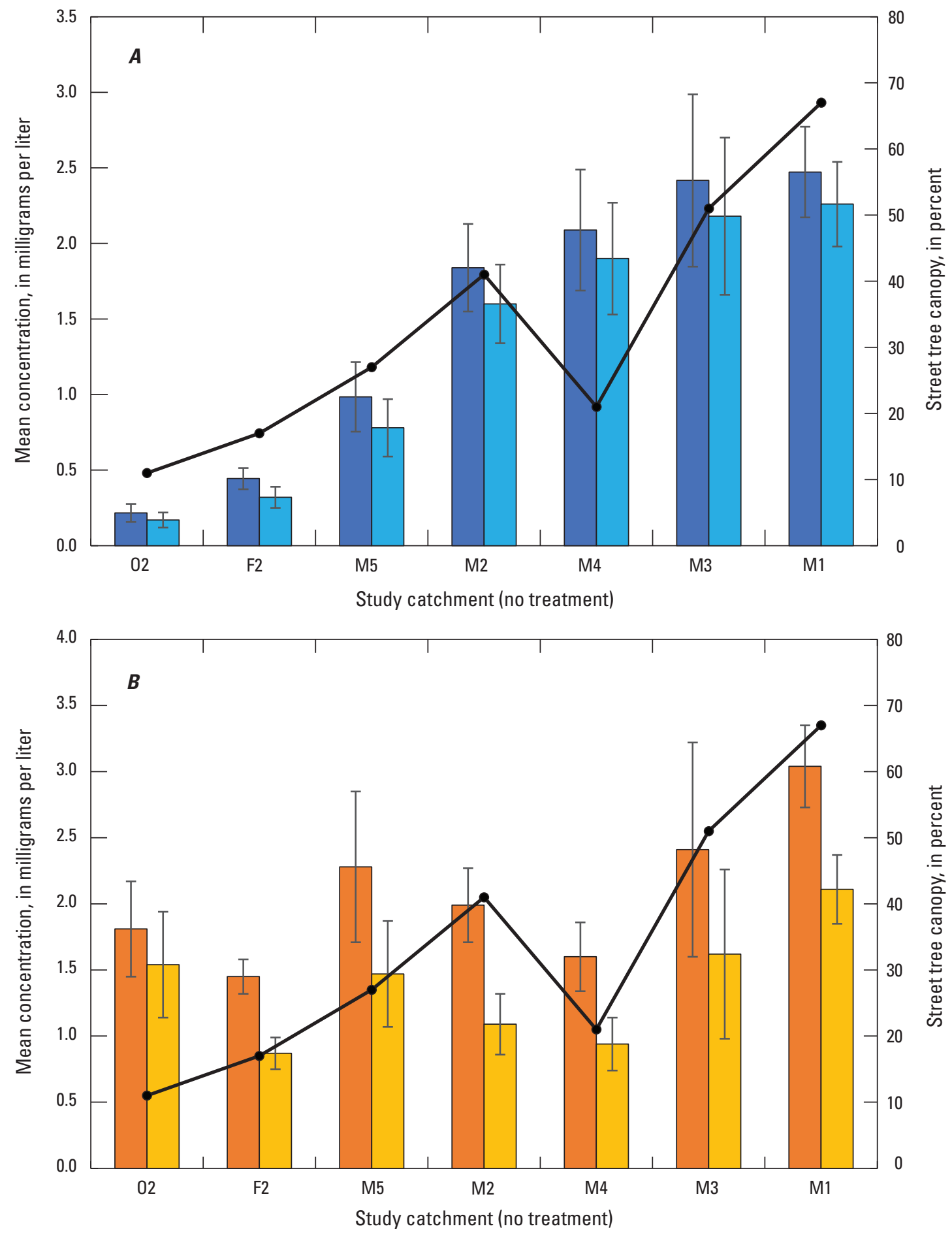

\section{EXPLANATION}

[Test site: F, Fondulac; M, Madison; 0, Oshkosh]

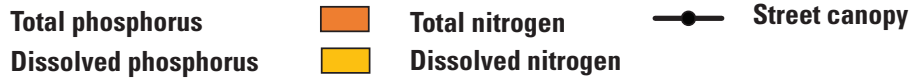

Figure 2. Site mean plus or minus standard error of $A$, event total phosphorus and dissolved phosphorus concentration and $B$, event total nitrogen and dissolved nitrogen concentration during a period of no leaf collection or street cleaning compared against the percentage of streets covered by tree canopy. Study catchments F1 and 01 are not shown because calibration and treatment periods in these catchments had some form of treatment. 
correlated to tree canopy, other contributing sources or denitrification processes may have affected nitrogen EMCs. Hobbie and others (2014) discovered periods of nitrogen immobilization (an increase in nitrogen mass) in urban leaf litter followed by release. These periods were assumed to coincide with the application of fertilizer on nearby turf grass. Selbig (2016) similarly observed elevated concentrations of nitrogen in the spring and fall that were presumed to be associated with application of lawn fertilizers.

Catchments having a street cleaning frequency of once per week, regardless of leaf collection method, had mean concentrations of TP and DP less than $1.40 \mathrm{mg} / \mathrm{L}$ (fig. 3A). At lower frequency (biweekly), street cleaning resulted in a mean TP and DP concentration of 1.69 and $1.51 \mathrm{mg} / \mathrm{L}$, respectively, indicating more phosphorus becomes available for leaching into runoff as the frequency of street cleaning decreases. M5, however, was an exception, having a biweekly leaf collection and street cleaning frequency, yet with mean concentrations of TP and DP that were less than catchments with a weekly schedule (fig. $3 A$ ). Mean concentrations in M5 during a period with no leaf collection or street cleaning (fig. $2 A$ ) show TP and DP to be 0.98 and $0.78 \mathrm{mg} / \mathrm{L}$, respectively; lower than all but two catchments and only slightly higher than mean concentrations in M5 during the treatment period as shown in figure $3 \mathrm{~A}$ ( $\mathrm{TP}=0.92 \mathrm{mg} / \mathrm{L}$ and $\mathrm{DP}=0.60 \mathrm{mg} / \mathrm{L}$ ). Therefore, leaf collection and street cleaning done biweekly in M5 was relatively ineffective at lowering mean concentrations. Conversely, a large reduction in mean concentrations of TP and DP was observed in the M3 catchment, with mean concentrations decreasing from 2.42 and $2.18 \mathrm{mg} / \mathrm{L}$, respectively, without any form of treatment to 0.75 and $0.63 \mathrm{mg} / \mathrm{L}$, respectively, when using vacuum-mulch leaf collection and regenerative-air street cleaning at a frequency of once per week (fig. $3 \mathrm{~A}$ ). Overall, larger reductions in mean concentrations of phosphorus and nitrogen were related to the frequency and not the form of treatment. A slightly weaker, but still significant, positive correlation was observed between mean concentrations of TP, DP, and street tree canopy $(r=0.78, p<0.05$ for TP and $r=0.79$, $p<0.05$ for DP) after treatment, whereas TN and DN (fig. $3 B$ ) failed to meet significance.

Dissolved nutrients, as a mean percentage of the total fraction in each catchment and treatment, are detailed in table 4. DP and DN made up the majority of phosphorus and nitrogen in all but one instance, indicating lower particulateassociated nutrients in stormwater runoff during the fall. The percentage of dissolved as a fraction of the total was more pronounced for DP than DN. Although seasonally variable fractions of dissolved and particulate phosphorus were not determined as part of this study, Selbig (2016) and Janke and others (2017) confirmed gradations in concentration and fraction by season. Lower values in both studies were reported during the summer months of June through September, a time of leaf maturity. During this period, contributions of phosphorus to stormwater runoff come primarily from sources other than leaves such as atmospheric deposition, erosion, and lawns (Janke and others, 2017). These studies also show nutrient concentrations in spring (April and May) that are appreciably higher than in summer due to the emergence of pollen and seeds. Spring and summer were also periods when phosphorus was primarily in the particulate phase (Selbig, 2016). During leaf senescence in the fall, most of the phosphorus is in the dissolved fraction as phosphorus is leached from an abundance of organic detritus on streets and in gutters. Because the majority of nutrient concentrations were in the dissolved fraction, source control through leaf removal may be one of the few treatment options available to environmental managers when reducing the amount of dissolved nutrients in stormwater runoff.

\section{Reduction in Nutrient Load from Municipal Leaf Collection and Street Cleaning Practices}

To test the nutrient reduction efficiency of various municipal leaf collection and street cleaning programs, loads from the control catchments were paired with loads from the test catchments to establish a quantifiable relation using linear regression. According to the paired-catchment approach, any change in the relation that was established between the control and test catchments during the calibration phase of the study can be attributed directly to activities related to leaf collection, street-cleaning, or both. The magnitude of change reflects the amount of organic material removed from streets by both frequency and method. Figure 4 illustrates the relations in fall loads of TP developed between the control and test catchments during the calibration and V1-R1 treatment phase in 2017. Differences in these relations were quantified if results of the ANCOVA test for differences in slopes and intercepts exceeded 85 percent statistical significance $(p \leq 0.15)$.

Additional figures for TP, DP, TN, and DN are available in appendix 1.

Quantification of the overall efficiency of municipal leaf collection and street cleaning practices at removing leaf litter and other organic detritus is represented as a percent reduction in nutrient load shown in figure 5. Similar to mean concentrations, percent load reductions showed strong positive correlation to the percentage of street tree canopy $(r=0.95, p<0.05$ for TP and $r=0.90, p<0.05$ for DP). A greater reduction was observed for DP than TP in all but one instance (fig. $5 \mathrm{~A}$ ). This result was expected given that most of the phosphorus resides in the dissolved fraction during the fall (table 4). Visual observation of the movement of leaves and other organic detritus, as a gross pollutant, showed transport to storm sewers is limited for most runoff events. This was later confirmed when use of trash nets attached to the storm sewer outfalls in select catchments only captured a small amount of leaves. Therefore, removal of leaf litter in waterways or intercepting structures will do little to reduce the total stormwater nutrient load. Allison and others (1998) made a similar conclusion after noting the nutrient contribution of coarse leaf litter $(>5 \mathrm{~mm})$ found in a stormwater treatment vault was approximately two orders of magnitude lower than what was 

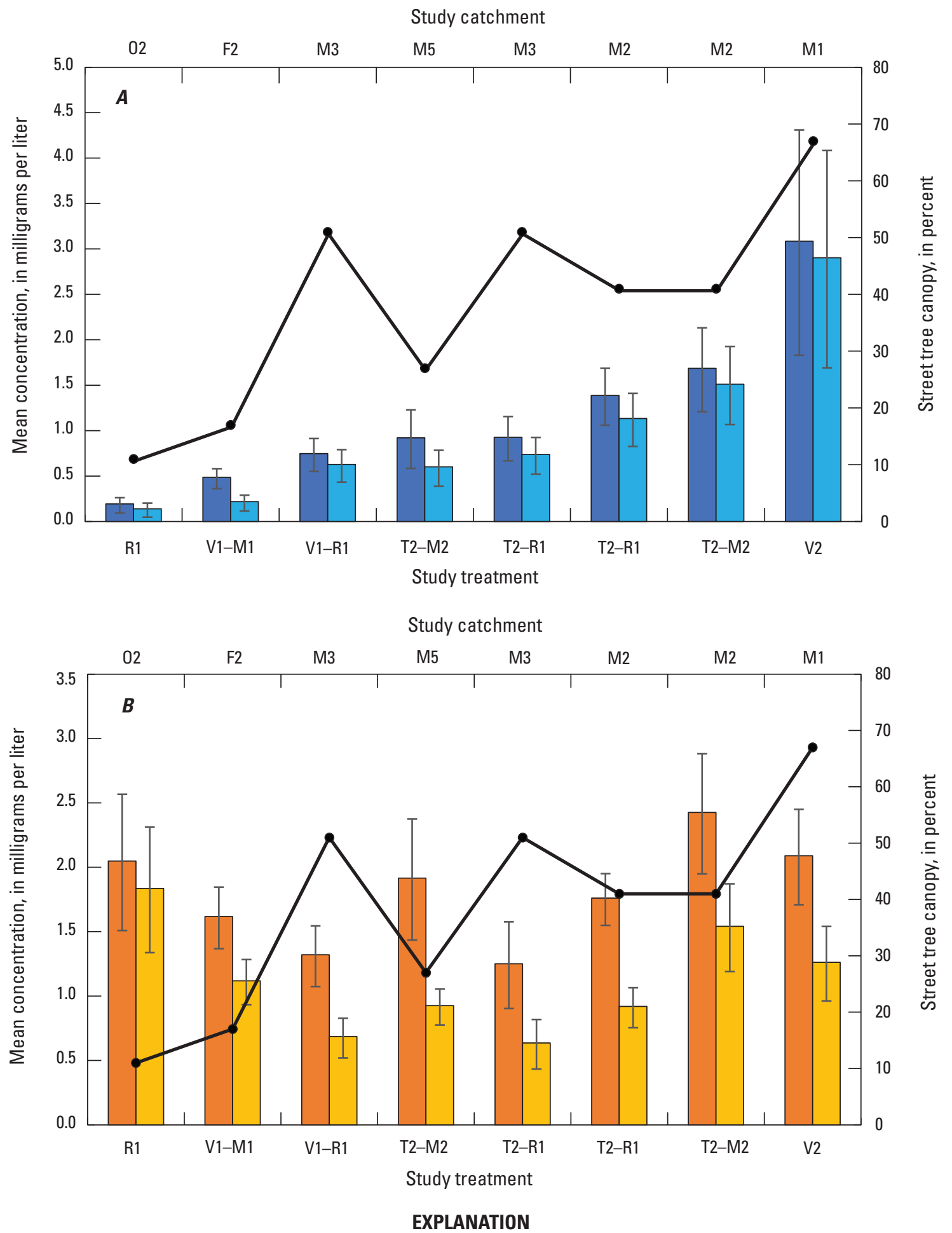

[Test site: F, Fondulac; M, Madison; 0, Oshkosh. Leaf collection methods; T, transfer; V, vacuum-mulch; $\mathrm{R}$, regenerative-air; $\mathrm{M}$, mechanical broom, See table 3]

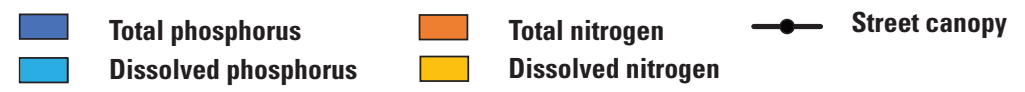

Figure 3. Site mean plus or minus standard error of $A$, event total phosphorus and dissolved phosphorus concentration and $B$, event total nitrogen and dissolved nitrogen concentration after treatment compared against the percentage of streets covered by tree canopy. 
Table 4. Dissolved phosphorus and dissolved nitrogen as a percentage of the total fraction for paired samples collected during the calibration and treatment phases.

[An explanation of the abbreviations used in this table can be found in figure 1 and table 3: --, not measured]

\begin{tabular}{|c|c|c|c|c|c|c|c|}
\hline \multicolumn{8}{|c|}{ Treatment } \\
\hline Catchment & Calibration & V1-R1 & V1-M1 & T2-R1 & T2-M2 & R1 & V2 \\
\hline \multicolumn{8}{|c|}{ Dissolved phosphorus } \\
\hline M1 & 91 & -- & -- & -- & -- & -- & 92 \\
\hline M2 & 85 & -- & -- & 79 & 85 & -- & -- \\
\hline M3 & 89 & 79 & -- & 76 & -- & -- & -- \\
\hline M4 & 89 & -- & -- & -- & -- & -- & -- \\
\hline M5 & 77 & -- & -- & -- & 66 & -- & -- \\
\hline $\mathrm{F} 1$ & -- & -- & 58 & -- & -- & -- & -- \\
\hline $\mathrm{F} 2$ & 70 & -- & 44 & -- & -- & -- & -- \\
\hline $\mathrm{O} 1$ & -- & -- & -- & -- & -- & 65 & -- \\
\hline $\mathrm{O} 2$ & 75 & -- & -- & -- & -- & 60 & -- \\
\hline \multicolumn{8}{|c|}{ Dissolved nitrogen } \\
\hline M1 & 70 & -- & -- & -- & -- & -- & 59 \\
\hline M2 & 54 & -- & -- & 51 & 70 & -- & -- \\
\hline M3 & 63 & 55 & -- & 49 & -- & -- & -- \\
\hline M4 & 56 & -- & -- & -- & -- & -- & -- \\
\hline M5 & 62 & -- & -- & -- & 53 & -- & -- \\
\hline F1 & -- & -- & 52 & -- & -- & -- & -- \\
\hline F2 & 55 & -- & 69 & -- & -- & -- & -- \\
\hline $\mathrm{O} 1$ & -- & -- & -- & -- & -- & 87 & -- \\
\hline $\mathrm{O} 2$ & 79 & -- & -- & -- & -- & 85 & -- \\
\hline
\end{tabular}

measured in stormwater. Without special filtration media such as granulated ferric oxide or proprietary amendments (which may be hydraulically limited), dissolved-phase pollutants are often difficult to remove from aqueous solution (Erickson and others, 2007).

Catchments using a regenerative-air cleaner operating at a frequency of once per week had the largest reductions in TP and DP load, regardless of leaf collection method or frequency. The $\mathrm{O} 2$ catchment was an exception with no statistically significant change in phosphorus loads after weekly treatment. The lack of measurable load reduction in $\mathrm{O} 2$ could be due to contributions of phosphorus from leaf piles adjacent to the street that were left uncollected throughout the treatment period. However, there is evidence indicating the mass of leaf litter and other organic detritus on a street has more effect on the amount of phosphorus in runoff than leaves piled adjacent to the street. This is best illustrated in the M1 catchment which, despite having the highest street canopy, showed no significant reduction in phosphorus load after using a vacuum-mulch method to remove leaf piles from the side of the street on a biweekly schedule (fig. $5 A$ ). Street cleaning was not done in M1 during this period, which allowed the accumulation of leaves in the street to overwhelm any reduction in phosphorus that may have occurred from leaf pile collection on the side of the street. No significant reduction observed in the $\mathrm{O} 2$ catchment is more likely explained by the low street tree canopy. With the lowest street tree canopy of all catchments (4 percent), the mass of leaf litter on streets in the $\mathrm{O} 2$ catchment was not enough to overcome the natural variability in phosphorus load with and without treatment (fig. $5 A$ ). It is not until street tree canopy reaches 30 percent before weekly removal of leaf litter and street cleaning is enough to produce significant reductions in phosphorus load, as observed in the F2 catchment. This indicates a threshold may exist where the frequency of treatment and the amount of street tree canopy can determine when leaf collection and street cleaning may no longer be effective. M2, having a street tree canopy of 41 percent, was the only catchment with biweekly leaf collection and street cleaning that significantly reduced phosphorus loads. The level of treatment in M2 was replicated in the M5 catchment; however, with a street tree canopy of only 27 percent, M5 showed no significant reduction in phosphorus loads $(p>0.15)$. Based on these observations, weekly leaf collection and street cleaning in the fall may be a viable option to reduce phosphorus load in stormwater runoff when street tree canopy has a minimum range of 4 to 30 percent. When 


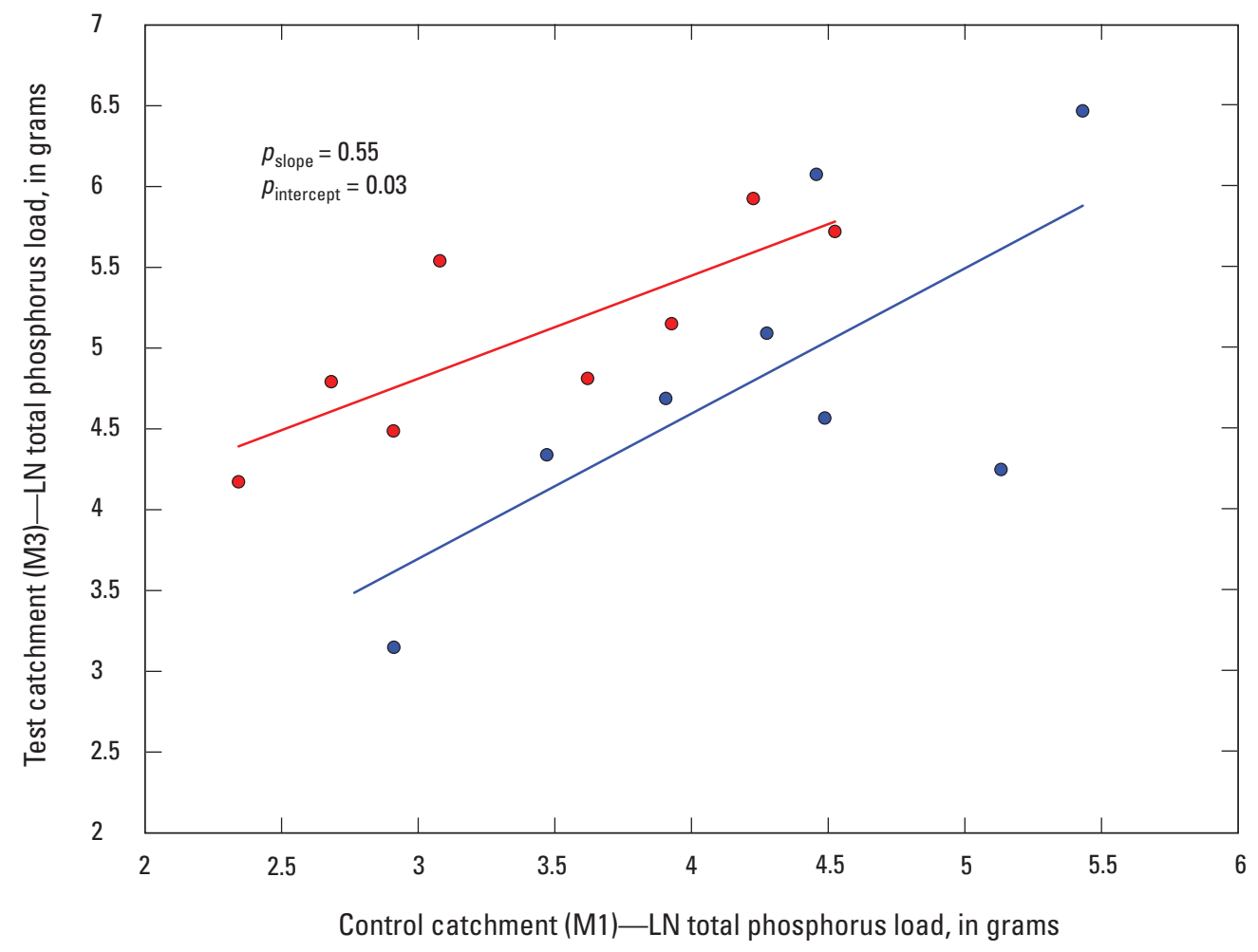

EXPLANATION

[Test site: M, Madison. LN, log transformed]

- Calibration

- Treatment

Figure 4. Log-transformed total phosphorus load for paired samples collected in the control and test catchment during the calibration and V1-R1 treatment phase. Statistical significance of the difference between slopes and intercepts are indicated by corresponding probability values $(p)$.

treating at a biweekly frequency, the minimum range increases to 27 to 41 percent. More research is needed to validate this assertion and to better define areas where leaf collection and street cleaning would most significantly reduce phosphorus loads in stormwater runoff.

Factors other than canopy may also determine the efficacy of treatment. As seen from figure $5 \mathrm{~A}$, the method and frequency of street cleaning has greater influence on phosphorus load reduction than that of leaf collection. Using the transfer method of leaf pile removal on a biweekly schedule was as effective as vacuum-mulching on reducing phosphorus loads, as long as the streets were cleaned on a weekly schedule using a regenerative-air street cleaner. The difference between a regenerative-air and mechanical broom street cleaner was further explored in the M2 catchment. Having the same street tree canopy and leaf collection method and frequency, a 57 percent reduction in TP was measured when using a regenerative-air cleaner compared to only a 40 percent reduction when using a mechanical broom. It is unclear whether TP reductions would have been greater if the mechanical broom street cleaner had been operated at a similar frequency as the regenerative-air at once per week; however, data presented in figure $5 \mathrm{~A}$ indicates more frequent removal of leaf litter and organic detritus from streets will reduce the amount of available phosphorus during subsequent runoff events. The importance of leaf litter removal in urban areas is further demonstrated by Hobbie and others (2017) who observed that phosphorus mobilized to impervious street surfaces via leaf litter, snowmelt, erosion, and deposition is essentially cutoff from ecosystem uptake thereby promoting export into storm drains. Hobbie and others (2017) suggest management efforts would benefit from a focus on minimizing transfer of phosphorus from vegetated landscapes to streets.

Reductions in nitrogen loads were not as predictable or prevalent as they were for phosphorus (fig. $5 B$ ). Of the seven treatments evaluated, three resulted in significant reductions for TN and only one for DN. Two of the treatments resulted in increased nitrogen load. Nitrogen reduction only occurred in catchments with weekly street cleaning; however, there was no clear trend in the magnitude of reduction nor any significant correlation to street tree canopy $(r=-0.70, p=0.19$ for $\mathrm{TN})$. 

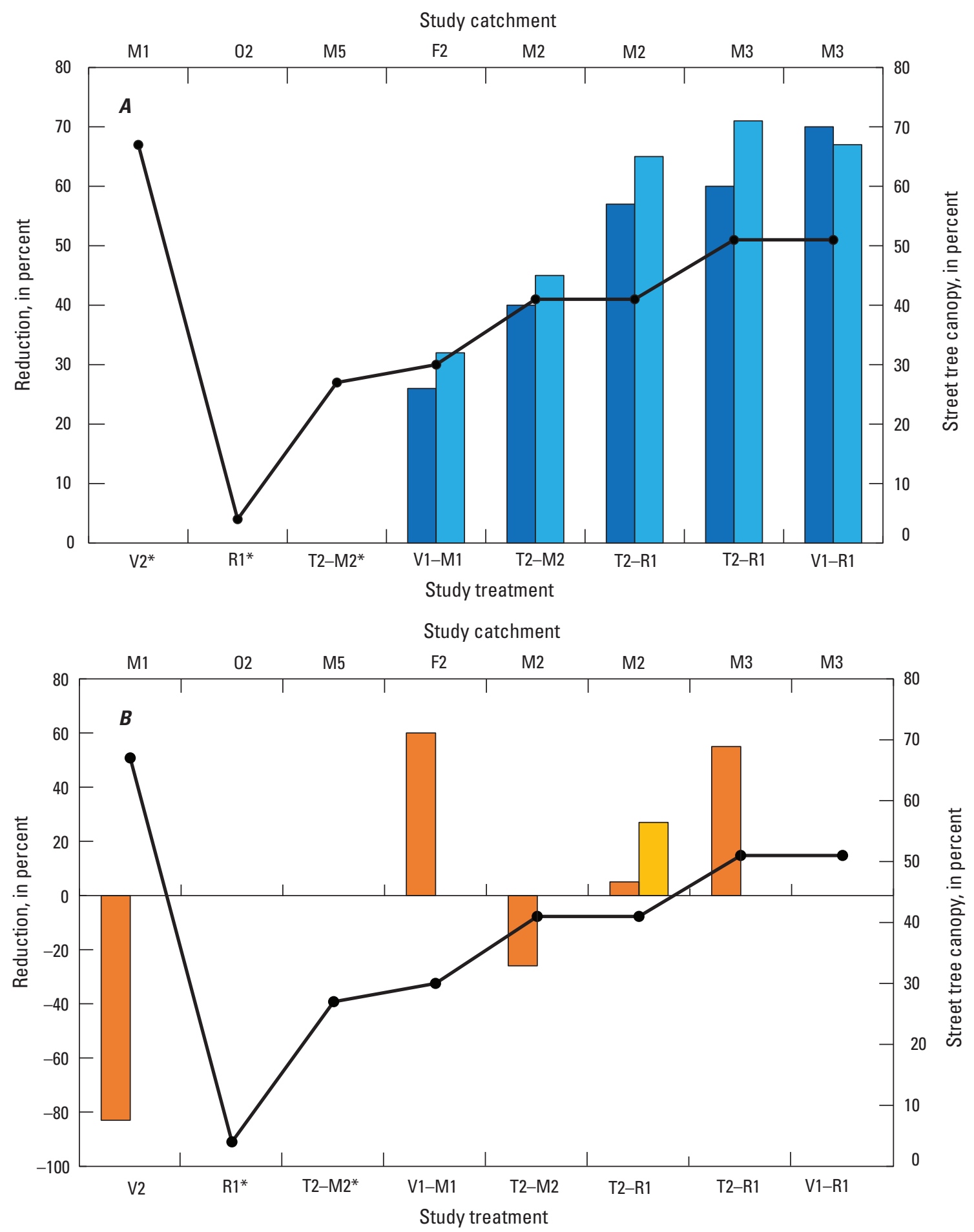

EXPLANATION

[Test site: F, Fondulac; M, Madison; 0, Oshkosh. Leaf collection methods; $T$, transfer; $\mathrm{V}$, vacuum-mulch; $\mathrm{R}$, regenerative-air; M, mechanical broom; * , not statistically significant; see table 3]

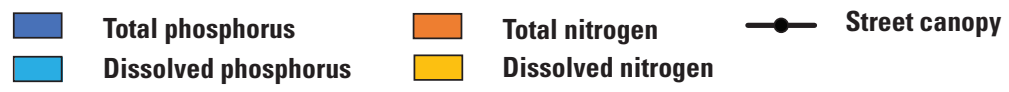

Figure 5. Percent reduction of $A$, event total phosphorus and dissolved phosphorus load and $B$, event total nitrogen and dissolved nitrogen load after treatment compared against the percentage of streets covered by tree canopy. $A$ negative value indicates an increase in load. 
The catchment with the highest percent street tree canopy (M1) also had the highest increase of TN (fig. 5B). Removal of leaf piles alone without street cleaning in the M1 catchment did not translate into a reduction in TN load. Like phosphorus, the frequency of street cleaning has more influence on TN load reduction than the method or frequency of leaf collection.

Unlike phosphorus, urban catchments can have high nitrogen retention. Laboratory studies have shown nitrogen to be relatively insoluble and not readily leached from leaf litter. For example, experiments by Uselman and others (2012) found only 11 percent of nitrogen was leached from leaf litter submersed in deionized water after 24 hours compared to 72 percent of soluble phosphorus. This result was replicated by Hobbie and others (2014) when measuring loss of nitrogen in five different species of air-dried leaf litter. Retention of nitrogen has also been shown at the catchment level. A comparison of inputs, outputs, and retention of nitrogen in seven urban watersheds with street tree canopy ranging from 20 to 36 percent showed an area-weighted watershed mean of 80 percent retention of net nitrogen inputs, with primary losses via leaching to groundwater (Hobbie and others, 2017). Nitrogen has also been shown to be linked to dynamic microbial gutter processes and landscape practices that promote denitrification (Yang and Toor, 2018; Hobbie and others, 2014). In contrast, other studies recognize vegetation as an abundant source of nitrogen, although uncertainty in speciation tends to fluctuate between particulate and dissolved forms (Taylor and others, 2005). Lusk and others (2020) reported leaf litter from oak trees contributed up to 76 percent of particulate organic nitrogen in stormwater samples and that failure to remove this source in a timely manner could lead to increased labile dissolved organic nitrogen. The directly connected nature of streets and storm sewers decreases detention time thereby limiting the opportunity for nutrient cycling and thus increasing levels of dissolved nitrogen (Galloway and others, 2003). If left unmitigated, leaf litter may continue to be a source of nitrogen long after leaves initially appeared on street surfaces. This is most evident in the M1 catchment where excessive buildup of leaf litter in streets, due to the absences of street cleaning, showed 83 percent more total nitrogen load than the calibration period (fig. $5 B$ ). In northern climates, Bratt and others (2017) measured seasonally high nitrogen export in snowmelt from urban catchments in Saint Paul, Minn. The sources of nitrogen were primarily microbially processed from leaf litter that accumulated during late fall and were flushed from street surfaces during early spring snowmelt.

Sources of nitrogen in urban catchments can also be introduced by homeowner behavior. Fertilizer has long been recognized as an anthropogenic source of nitrogen and phosphorus to urban runoff causing localized "hot spots" from its use in residential land management practices (Cowen and Lee, 1973; Templer and others, 2015; Janke and others, 2017; Hobbie and others, 2017). Lawns applied with nitrogen-rich fertilizer, the application being typically done in spring and fall in the Midwest, could serve as a source of nitrogen to end-of-pipe concentrations that would not be affected by leaf collection and street cleaning practices. Although seasonal application of fertilizers were expected to have been consistent in the calibration and treatment phases of the study, the timing of individual homeowner application would have varied. This anthropogenic source of nitrogen could become more pronounced if closely tied to a runoff event. Without knowledge of individual homeowner practices, it is difficult to determine how fertilizers effected nitrogen load in stormwater runoff. Although fertilizer may have been a source of nitrogen, it was not a concern for phosphorus since the State of Wisconsin enacted a ban on phosphorus in lawn and turf fertilizer in 2009 (Wisconsin State Legislature, 2020).

\section{Implications for Urban Stormwater Management}

Results from this study indicate the frequency of municipal leaf collection and street cleaning has more effect on mitigating nutrient loads in stormwater runoff in the fall than does the form of leaf collection. The link between concentrations of phosphorus and nitrogen measured in storm drains and street tree canopy support stormwater management practices that are designed to limit accumulation of leaf litter on streets or encourage their removal before a storm event. For cities with limited resources, removal efforts could be placed on areas with the highest street tree canopy first. Use of a highefficiency street cleaner, when operated on a weekly schedule, would provide maximum benefit; however, collection of leaf piles remains an important part of managing phosphorus and nitrogen loads, because most homeowners have come to rely on that service to dispose of excess yard waste. This is especially true if local ordinances do not prohibit leaf piles from being placed in the street.

Phosphorus and nitrogen from leaf piles placed in the terrace versus the street are less of a concern to the overall increase of nutrients in urban runoff. Leaves accumulated in piles on the terrace would likely retain and store an appreciable amount of precipitation before contributing to runoff. Once the storage capacity is exceeded, water percolating through a leaf pile slowly infiltrates into underlying soils thereby limiting nutrient-rich runoff from reaching the street. Eventually, with enough precipitation, or with high precipitation intensity, the retentive properties of leaf piles would be exceeded. At this point, leaf piles would become additional sources of phosphorus and nitrogen beyond just leaf litter in the street. Removal of leaf piles before such large events occur would be an effective preventative strategy, the success of which would depend on the frequency of collection. Methods used to remove leaf piles are expected to minimize the amount of leaf residue after collection.

In fall, the amount of phosphorus and nitrogen in urban stormwater is largely determined by the cleanliness of streets before a precipitation event. At its peak, fall leaf litter can 
rapidly accumulate on a street surface over a short period of time. Because the amount of leachable phosphorus in runoff is a function of the amount of time a leaf is exposed to stormwater, the timing of leaf collection and street cleaning is an important factor when maximizing phosphorus and nitrogen load reduction. Events of longer duration can extract more nutrients from leaf litter than short duration events (Duan and others, 2014). Beyond municipal efforts, more work is needed to quantify nutrient reductions through changes in homeowner behavior. Public outreach campaigns to promote onsite retention of nutrients (for example, mulching or composting) and prevent increased export of nutrients, such as minimizing application of fertilizers, have qualitatively been effective but have not yet been quantified.

\section{Acknowledgments}

The authors would like to thank Kathy Stenehjem and Caitlin Wienkes of the U.S. Geological Survey for field operations and maintaining data integrity.

\section{References Cited}

Allison, R.A., Chiew, F.H.S., and McMahon, T.A., 1998, Nutrient contribution of leaf litter in urban stormwater: Journal of Environmental Management, v. 54, no. 4, p. 269-272. [Also avalailable at https://doi.org/10.1006/ jema.1998.0334.]

Baker, L.A., Kalinosky, P., and Hobbie, S.E., 2014, Quantifying nutrient removal by enhanced street sweeping, Stormwater Magazine, March/April, accessed January 28, 2020, at https://arrybakerlab.cfans.umn.edu/sites/ larrybakerlab.cfans.umn.edu/files/files/quantifying-nutrientremoval-compressed-file.pdf.

Bratt, A.R., Finlay, J.C., Hobbie, S.E., Janke, B.D., Worm, A.C., and Kemmitt, K.L., 2017, Contribution of leaf litter to nutrient export during winter months in an urban residential watershed: Environmental Science \& Technology, v. 51, no. 6, p. 3138-3147. [Also available at https://doi.org/10.1021/ acs.est.6b06299.]

Carvin, R.B., and Selbig, W.R., 2020, Stormwater-quality data in the control and test catchments during the calibration and treatment phase of a leaf collection study in Madison, Fond du Lac, and Oshkosh, Wisconsin, from September 2016 through November 2019: U.S. Geological Survey data release, https://doi.org/10.5066/P93L2WM1.

Clausen, J.C., and Spooner, J., 1993. Paired basin watershed study design: U.S. Environmental Protection Agency, Office of Water, EPA-841-F-93-009, 8 p.
Cowen, W.F., and Lee, G.F., 1973, Leaves as a source of phosphorus: Environmental Science \& Technology, v. 7, no. 9, p. 853-854. [Also available at https://doi.org/10.1021/ es60081a006.]

Dorney, J.R., 1986, Leachable and total phosphorus in urban street tree leaves: Water, Air, and Soil Pollution, v. 28, p. 439-443.

Duan, S., Delaney-Newcomb, K., Kaushal, S.S., Findlay, S.E.G., and Belt, K.T., 2014, Potential effects of leaf litter on water quality in urban watersheds: Biogeochemistry, v. 121, no. 1, p. 61-80. [Also available at https://doi.org/ 10.1007/s10533-014-0016-9.]

Erickson, A.J., Gulliver, J.S., and Weiss, P.T., 2007, Enhanced sand filtration for storm water phosphorus removal: Journal of Environmental Engineering, v. 133, no. 5, p. 485-497. [Also available at https://doi.org/10.1061/(ASCE)07339372(2007)133:5(485).]

Galloway, J.N., Aber, J.D., Erisman, J.W., Seitzinger, S.P., Howarth, R.W., Cowling, E.B., and Cosby, B.J., 2003, The nitrogen cascade: Bioscience, v. 53, no. 4, p. 341-356. [Also available at https://doi.org/10.1641/ 0006-3568(2003)053[0341:TNC]2.0.CO;2.]

Gilbert, P.M., and Burford, M.A., 2017. Globally changing nutrient loads and harmful algal blooms-Recent advances, new paradigms, and continuing challenges: Oceanography Society, v. 30, no. 1, p. 58-69, accessed February 12, 2020, at http://www.jstor.org/stable/24897842.

Helsel, D.R., and Hirsch, R.M., 2002, Statistical methods in water resources: Reston, Va., U.S. Geological Survey Techniques of Water-Resources Investigations of the United States Geological Survey, book 4, chapter A3, 522 p. [Also available at https://doi.org/10.3133/twri04A3.]

Hobbie, S.E., Baker, L.A., Buyarski, C., Nidzgorski, D., and Finlay, J.C., 2014, Decomposition of tree leaf litter on pavement-Implications for urban water quality: Urban Ecosystems, v. 17, no. 2, p. 369-385. [Also available at https://doi.org/10.1007/s11252-013-0329-9.]

Hobbie, S.E., Finlay, J.C., Janke, B.D., Nidzgorski, D.A., Millet, D.B., and Baker, L.A., 2017, Contrasting nitrogen and phosphorus budgets in urban watershed and implications for managing urban water pollution: Proceedings of the National Academy of Sciences of the United States of America, v. 114, no. 16, p. 4177-4182. [Also available at https://doi.org/10.1073/pnas.1618536114.]

Jaffe, M., Zellner, M., Minor, E., Gonzalez-Meler, M., Bucci Cotner, L., Massey, D., Ahmed, H., Elberts, M., Sprague, H., Wise, S., and Miller, B., 2010, The Illinois green infrastructure study: accessed February 18, 2020, at http://www.epa.state.il.us/green-infrastructure/docs/draftfinal-report.pdf. 
Janke, B.D., Finlay, J.C., and Hobbie, S.H., 2017, Trees and streets as drivers of urban stormwater nutrient pollution: Environmental Science \& Technology, v. 51, no. 17, p. 9569-9579. [Also available at https://doi.org/10.1021/ acs.est.7b02225.]

Law, N.L., DiBlasi, K., Ghosh, U., Stack, B., Stewart, S., Belt, K., Pouyat, R., and Welty, C., 2008, Deriving reliable pollutant removal rates for municipal street sweeping and storm drain cleanout programs in the Chesapeake Bay basin: Center for Watershed Protection, accessed February 20, 2020, at https://owl.cwp.org/mdocs-posts/ lawn-_deriving_reliable_polllution_removal_rates/.

Lusk, M.G., Toor, G.S., Inglett, P.W., 2020, Organic nitrogen in residential stormwater runoff-Implications for stormwater management in urban watersheds: Science of the Total Environment, v. 707, 8 p., https://doi.org/10.1016/ j.scitotenv.2019.135962.

Moore, J.W., Schindler, D.E., Scheuerell, M.D., Smith, D., and Frodge, J., 2003, Lake eutrophication at the urban fringe, Seattle region, USA: Ambio, v. 32, no. 1, p. 13-18. [Also available at https://doi.org/10.1579/0044-7447-32.1.13.]

Müller, A., Österlund, H., Marsalek, J., and Viklander, M., 2020, The pollution conveyed by urban runoff-A review of sources: Science of the Total Environment, v. 709, 18 p., https://doi.org/10.1016/j.scitotenv.2019.136125.

Selbig, W.R., and Bannerman, R.T., 2007, Evaluation of street sweeping as a stormwater-quality-management tool in three residential basins in Madison, Wisconsin: U.S. Geological Survey Scientific Investigations Report 2007-5156, p. 103. [Also available at https://doi.org/10.3133/sir20075156.]

Selbig, W.R., Cox, A., and Bannerman, R.T., 2012, Verification of a depth-integrated sample arm as a means to reduce solids stratification bias in urban stormwater sampling: Journal of Environmental Monitoring, v. 14, no. 4, p. 1138-1143. [Also available at https://doi.org/10.1039/c2em10999a.]

Selbig, W.R., 2016, Evaluation of leaf removal as a means to reduce nutrient concentrations and loads in urban stormwater: The Science of the Total Environment, v. 571, p. 124-133. [Also available at https://doi.org/10.1016/ j.scitotenv.2016.07.003.]

Shaver, E., Horner, R., Skupien, J., May, C., and Ridely, G., 2007, Fundamentals of urban runoff managementTechnical and institutional issues 2nd ed.: Madison, Wis., The North American Lake Management Society, 327 p.

Sorenson, J., 2012, Potential reductions of street solids and phosphorus in urban watersheds from street cleaning, Cambridge, Massachusetts, 2009-11: U.S. Geological Survey Scientific Investigations Report 2012-5292, p. 66., plus appendix 1 on a CD-ROM in pocket. [Also available at https://doi.org/10.3133/sir20125292.]
Steuer, J.J., Selbig, W.R., Hornewer, N.J., and Prey, J., 1997, Sources of contamination in an urban basin in Marquette, Michigan and an analysis of concentrations, loads, and data quality: U.S. Geological Survey Water Resources Investigation Report 97-4242, 25 p., https://doi.org/ 10.3133/wri974242.

Taylor, G.D., Fletcher, T.D., Wong, T.H.F., Breen, P.F., and Duncan, H.P., 2005, Nitrogen composition in urban runoff-Implications for stormwater management: Water Research, v. 39, no. 10, p. 1982-1989. [Also available at https://doi.org/10.1016/j.watres.2005.03.022.]

Templer, P.H., Toll, J.W., Hutyra, L.R., and Raciti, S.M., 2015, Nitrogen and carbon export from urban areas through removal and export of litterfall: Environ Pollution., v. 197, p. 256-261. [Also available at https://doi.org/10.1016/ j.envpol.2014.11.016.]

Uselman, S.M., Qualls, R.G., and Lilienfein, J., 2012, Quality of soluble organic $\mathrm{C}, \mathrm{N}$, and $\mathrm{P}$ produced by different types and species of litter-Root litter versus leaf litter: Soil Biology \& Biochemistry, v. 54, p. 57-67. [Also available at https://doi.org/10.1016/j.soilbio.2012.03.021.]

U.S. Environmental Protection Agency, [EPA], 1993, Method 353.2, revision 2.0-Determination of nitrate-nitrite nitrogen by automated colorimetry: Environmental Monitoring System Laboratory, accessed February 20, 2020, at https://www.epa.gov/sites/production/files/2015-08/ documents/method_353-2_1993.pdf.

U.S. Environmental Protection Agency, 2001, Method 200.7, revision 5.0-Trace elements in water, solids, and biosolids by inductively coupled plasma-atomic emission spectrometry, EPA-821-R-01-010: Washington, D.C., Office of Science and Technology, $68 \mathrm{p}$.

U.S. Environmental Protection Agency, [EPA], 2020, Clean water act section 303(d)-Impaired waters and total maximum daily loads (TMDLs): Environmental Protection Agency web page, accessed February 12, 2020, at https://water.epa.gov/lawsregs/lawsguidance/cwa/tmdl.

Waschbusch, R.J., Selbig, W.R., and Bannerman, R.T., 1999, Sources of phosphorus in stormwater and street-dirt from two urban residential basins in Madison, Wisconsin, 1994-95: U.S. Geological Survey Water-Resources Investigations Report 99-4021, 47 p.

Wisconsin State Legislature, 2020, Plant industry: Wisconsin State Legilature web page, accessed January 30, 2020, at https://docs.legis.wisconsin.gov/statutes/statutes/94/643.

Wurtsbaugh, W.A., Paerl, H.W., and Dodds, W.K., 2019, Nutrients, eutrophication and harmful algal blooms along the freshwater to marine continuum: Wires Water, v. 6, no. 5, 27 p., https://doi.org/10.1002/wat2.1373. 
Yang, Y., and Toor, G.S., 2018, Stormwater runoff driven phosphorus transport in an urban residential catchmentImplications for protecting water quality in urban watersheds: Scientific Reports, v. 8, no. 1, 8 p., https://doi.org/ 10.1038/s41598-018-29857-x. 


\section{Appendix 1. Paired-Basin Nutrient Loads in the Control and Test Catchments During Calibration and Treatment Phases}

The graphs, located at https://doi.org/10.3133/

sir20205109, show log-transformed loads for paired samples of total phosphorus, dissolved phosphorus, total nitrogen, and dissolved nitrogen collected in the control and test catchment during the calibration and treatment phases of the study. The graphs are ordered by year of completion. Statistical significance of slopes and intercepts are indicated by corresponding probability values $(p)$. A description of the nomenclature used in the title of each figure can be found in table 3 of the manuscript. 

For additional information contact:

Director, Upper Midwest Water Science Center U.S. Geological Survey

8505 Research Way

Middleton, WI 53562

Publishing support provided by the Indianapolis Publishing Service Center 


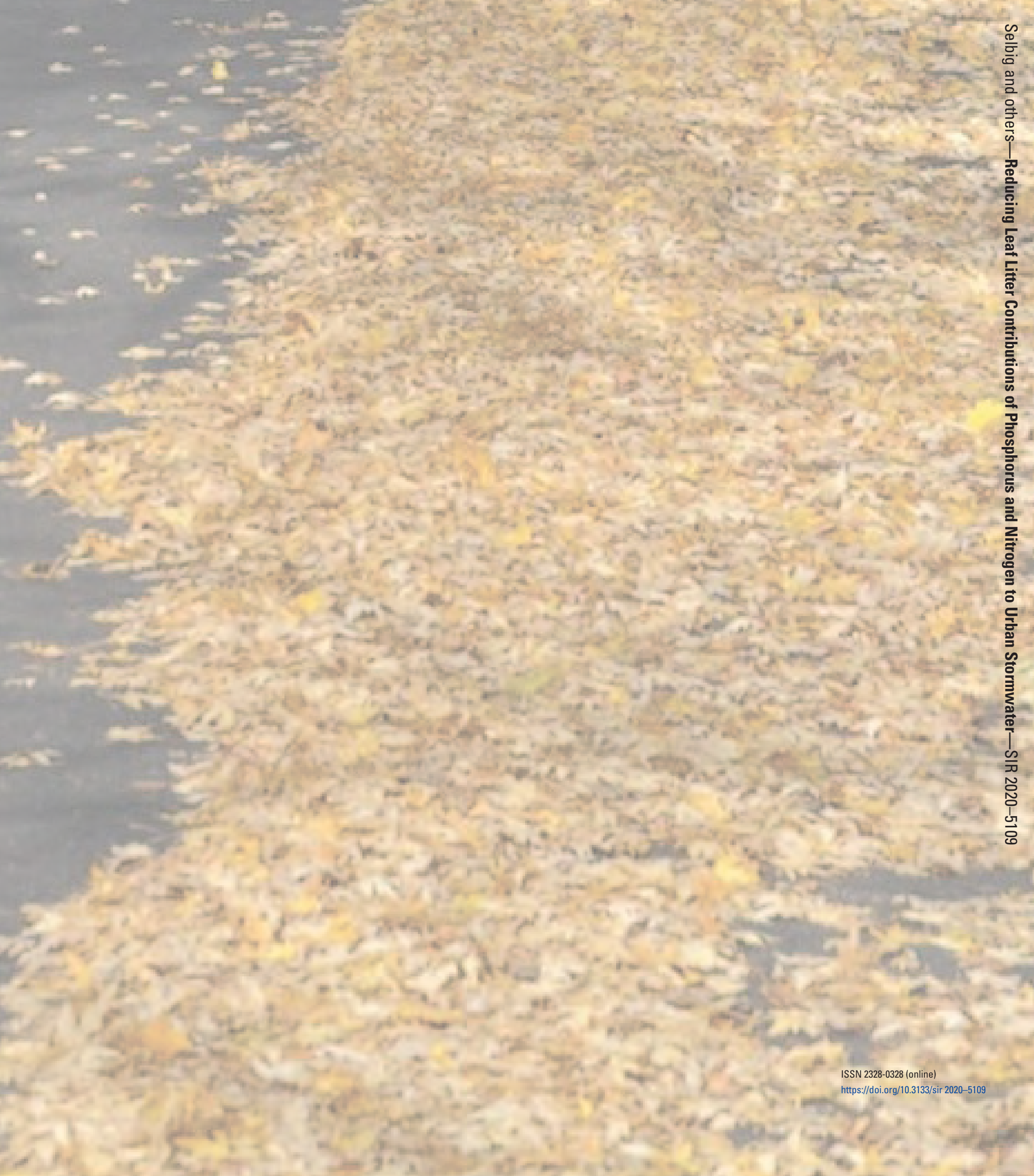

